Volume 2, Number 2, 2016

\title{
Calculation of Expansibility Factor of Gas at Its Flow Through an Orifice Plate with Flange Pressure Tappings
}

\author{
Yevhen Pistun, Leonid Lesovoy* \\ Lviv Polytechnic National University, 12 Stepan Bandera St., Lviv, 79013, Ukraine
}

(C) 2016 The Authors. Published by Lviv Polytechnic National University.

Received: October 9, 2015. Revised: February 26, 2016. Accepted: December 26, 2016.

\begin{abstract}
The values of expansibility factor of gas were defined more accurately based on the values obtained by Seidl in CEESI using the equation of mass flowrate and on the basis of experimental data (differential pressure across the orifice plate, mass flowrate, absolute static pressure and temperature of air) for orifice plates with flange pressure tappings and diameter ratios of $0.242,0.363,0.484,0.5445,0.6655,0.728$ and pipe internal diameter of $52.48 \mathrm{~mm}(2.066 \mathrm{in}$.$) . When obtaining the$ values of expansibility factor of gas, the Stolz equation was used by Seidl to calculate the discharge coefficient for Reynolds numbers equal to infinity. New values of expansibility factor of gas are defined more accurately by us with taking into account the Reader-Harris/Gallagher equation for calculating the discharge coefficient for the actual Reynolds numbers of gas in the pipe. Based on these new more accurate data a new equation for calculating the expansibility factor of gas for orifice plate with flange pressure tappings is developed. The comparison and analysis of the expansibility factor calculated according to the equation given in ISO 5167:2-2003 and according to the new developed equation is presented in the paper. The equation in ISO 5167:2-2003 for computing the gas expansibility factor is developed for all three types of pressure tappings arrangement. In this case the scattering of discharge coefficient values being applied for deriving the expansibility factor equation is large for the same set of input data. It is shown that the shortcomings mentioned above are eliminated in the new equation and the standard deviation of the expansibility factor calculated according to the new equation from the new accurate experimental values is smaller. New formula for calculating the relative expanded uncertainty of expansibility factor for orifice plate with flange pressure tappings is also presented in the paper.
\end{abstract}

Keywords: expansibility factor; flowrate measurement; orifice plate; flange tappings.

\section{Introduction}

The pressure differential method with a standard primary device is the most widespread method for measurement of flowrate and volume of fluid energy carriers. One of the ways to improve the accuracy of flowrate and volume measurement is development and application of new formulae for calculating the coefficients of the flowrate equation to provide reduction of uncertainty when calculating these coefficients. The expansibility factor of gas is a part of the flowrate equation and improvement of accuracy of this factor is very important. This work deals with defining the experimental values of the expansibility factor for gas more accurately and the new equation for calculating the gas expansibility factor more accurately is developed.

\section{Analysis of recent research works and publications}

The firs experimental research works for expansibility factor of gas were carried out in Los Angeles in 1929. Based on these works Buckingham [1] derived an equation for defining the gas expansibility factor $\varepsilon_{B}$ as follows

$$
\varepsilon_{B}=1-\left(0.41+0.35 \beta^{4}\right) \frac{\Delta p}{p \cdot \kappa},
$$

\footnotetext{
"Corresponding author. Email address: techinfoflow@yahoo.co.uk
} 
where $\beta$ is diameter ratio of orifice plate; $\Delta p$ is differential pressure across the orifice plate; $p$ is absolute pressure; $\kappa$ is isentropic exponent.

The equation (1) was included in the following normative documents ISO 5167-91 [2], RD 50-213-80 [3] and GOST 8.563.1-97 [4].

But the influence of Reynolds number on discharge coefficient of orifice plate was neglected by Buckingham when analyzing the experimental data. He considered that discharge coefficient for Reynolds numbers higher than $2 \cdot 10^{5} \cdot \beta$ is constant. According to the recent experimental data [5]-[9] the discharge coefficient varies at $\operatorname{Re}>2 \cdot 10^{5} \cdot \beta$. Nevertheless the general structure of this equation was the basis for other equations for calculation of gas expansibility factor.

Thibessard [10] has proposed another structure of equation for calculating the gas expansibility factor $\varepsilon_{T}$

$$
\varepsilon_{\mathrm{T}}=1-\left(a+b \beta^{4}\right)\left(1-\tau^{\frac{1}{\kappa}}\right)^{c},
$$

where $\tau$ is defined according to the equation

$$
\tau=1-\frac{\Delta p}{p}
$$

The value of coefficient $\mathrm{c}$ is equal to 0.935 . This value was later taken equal to unity by Reader-Harris [11].

Experimental research works on air expansibility factor were carried out by Reid J. [12] at National Engineering Laboratory (NEL) for pipe internal diameter of $100 \mathrm{~mm}$ (4-inch), for three diameter ratios $(0.2006 ; 0.57 ; 0.7501)$, for orifice plate with various types of tappings and for absolute pressure of air in the range of 140 to $800 \mathrm{kPa}$. The mass flowrate of air was set by means of reference sonic nozzle. It provided the Reynolds number of air flow which could be considered to be constant. The Reynolds number deviations were not more than $2 \%$ of the mean value of Reynolds number. During the experiments [12] the expansibility factor was defined a

$$
\varepsilon_{1}=\frac{\left(C \varepsilon_{1}\right)_{\mathrm{g}}}{C_{\mathrm{w}}},
$$

where $\left(C \varepsilon_{1}\right)_{\mathrm{g}}$ is the measured value of product of discharge coefficient and expansibility factor of air for the same orifice plate, $C_{w}$ is the orifice plate discharge coefficient calculated for water according to Stolz equation [2].

Based on the experimental data, a new formula for gas expansibility factor $\varepsilon_{1}$ was proposed by NEL [12]

$$
\varepsilon_{1}=1-a-b \cdot \mathrm{f}\left(\frac{\Delta p}{p}, \kappa\right)
$$

The coefficient $b$ in equation (5) is the slope coefficient which depends on the orifice plate diameter ratio.

The experimental data for orifice plate diameter ratio of $\beta=0.2006$ were later defined more accurately by NEL [13] and a new formula for calculating the gas expansibility factor $\varepsilon_{2}$ was derived as follows

$$
\varepsilon_{2}=\frac{\varepsilon_{1}}{1-a}=1-b^{*} \cdot \mathrm{f}\left(\frac{\Delta p}{p}, \kappa\right),
$$

where $b^{*}$ is the coefficient which depends on the orifice plate diameter ratio and is defined as follows

$$
b^{*}=\frac{b}{1-a} .
$$


Experimental data for air expansibility factor were obtained by Seidl [14] for orifice plates with flange pressure tappings with the diameter ratios of $0.242,0.363,0.484,0.5445,0.6655$ and 0.726 , for pipe with the internal diameter of $52.48 \mathrm{~mm}$ and the absolute pressure of air in the range of 115 to $2150 \mathrm{kPa}$.

The experimental data were obtained for orifice plate installed upstream of reference sonic Venturi nozzle. The inlet pressure and temperature of air upstream of the reference sonic Venturi nozzle were regulated to maintain the constant value of mass flowrate of air and the Reynolds number. The heat exchanger was installed upstream of orifice plate to provide minimal variations of temperature and of Reynolds number correspondingly.

Since the mass flowrate of air was maintained constant, the main part of the uncertainty of flowrate measurement was caused by measurement of static pressure of air and by measurement of differential pressure across the orifice plate. The static pressure of air was measured by means of a quartz manometer of overpressure with the uncertainty of measurement of $\pm 0.012 \%$. The differential pressure across the orifice plate was measured by means of two intellectual measuring transducers. The ambient temperature variations and variations of static pressure of air in the pipe were compensated by these measuring transducers. The differential pressure measuring transducers were maid by two different companies and the result of differential pressure measurement was the mean value of the readings of the two measuring transducers. The uncertainty of differential pressure measurement was equal $\pm 0.1 \%$. The air temperature was measured by means of a thermoelectric couple with the uncertainty of $\pm 0.1^{\circ} \mathrm{C}$.

The expansibility factor $\varepsilon_{S}$ was defined by Seidl according to the following equation [14]

$$
\varepsilon_{\mathrm{S}}=\frac{4 \cdot q_{m}}{\pi \cdot C_{\infty} \cdot \beta^{2} \cdot D^{2}} \cdot \sqrt{\frac{1-\beta^{4}}{2 \cdot \rho_{1} \cdot \Delta p}},
$$

where $q_{m}$ is the air mass flowrate which was set by means of reference sonic Venturi nozzle, $C_{\infty}$ is discharge coefficient calculated for incompressible fluid according to Stolz equation at Reynolds number equal to infinity, $\rho_{1}$ is air density upstream of the orifice plate with flange pressure tappings at absolute pressure $p$ and thermodynamic temperature $T$.

Based on the equations (2) and (3), a new formula for calculating expansibility factor of gas at its flow through an orifice plate with any type of pressure tapping arrangement was derived by Reader-Harris [11]. This equation was included in ISO 5167-2:2003 [15]. The gas expansibility factor $\varepsilon_{R H}$ for orifice plates with any type of pressure tapping arrangement according to [11] is calculated as follows

$$
\varepsilon_{\mathrm{RH}}=1-\left(0.351+0.256 \beta^{4}+0.93 \beta^{8}\right)\left[1-\left(1-\frac{\Delta p}{p}\right)^{\frac{1}{\kappa}}\right],
$$

Based on the analysis of the existing formulae for the calculation of expansibility factor $\varepsilon$ and by comparing these formulae with the existing experimental data, we defined that all the formulae do not provide minimal errors and minimal systematic errors in particular due to the following factors:

- equations (1) and (9) for calculation of gas expansibility factor are derived by Buckingham [1] and ReaderHarris [11] with application of Stolz equation but not with application of the more accurate ReaderHarris/Gallagher equation [5, 6] for calculation of orifice plate discharge coefficient;

- the experimental values of gas expansibility factor were defined for orifice plate discharge coefficients $C_{\infty}$ calculated for Reynolds numbers equal to infinity but not for the actual Reynolds numbers;

- equations (1) and (9) for calculation of gas expansibility factor were derived for orifice plates with any type of pressure tapping arrangement but for various types of pressure tapping arrangement the values of discharge coefficients vary considerably at the same input data which makes influence on the gas expansibility factor.

All these factors lead to overstatement of gas expansibility factors calculated according to equations (1) and (9) in comparison to the experimental data obtained by Seidl [14] for gas flow through an orifice plate with flange pressure tappings. The calculated results of gas expansibility factors according to equations (1) and (9) include a systematic component error which is not desirable for calculation of gas flowrate and volume. 
The objective of this work is to define the experimental values of gas expansibility factor more accurately based on the experiments carried out by Seidl [14] and to develop a new equation for calculation of expansibility factor of gas at its flow though an orifice plate with flange pressure tappings in order to provide higher accuracy of flowrate calculation.

\section{Correction of experimental data}

Let's recalculate the experimental values of expansibility factor $\varepsilon_{S}$ of air obtained by Seidl [14], using ReaderHarris/Gallagher equation [15] for discharge coefficient $C_{R H}$ for orifice plates with flange pressure tappings according to the following equation

$$
\varepsilon_{\mathrm{Ne}}=\varepsilon_{\mathrm{S}} \frac{C_{\infty}}{C_{\mathrm{RH}}} .
$$

The value of discharge coefficient $C_{\infty}$ for an orifice plate with flange pressure tappings was calculated according to Stolz equation [2] for Reynolds number equal to infinity as follows

$$
C_{\infty}=0.5959+0.0312 \beta^{2.1}-0.184 \beta^{8}+0.09 L_{1} \frac{\beta^{4}}{1-\beta^{4}}-0.0337 \cdot L_{2} \beta^{3},
$$

where $L_{1}$ and $L_{2}$ for orifice plates with flange pressure tappings are calculated in the following way

$$
\begin{gathered}
L_{1}= \begin{cases}0.4333 & \text { for } D \leq 0.05862 \mathrm{~m} ; \\
\frac{0.0254}{D} & \text { for } D>0.05862 \mathrm{~m} ;\end{cases} \\
L_{2}=\frac{0.0254}{D} .
\end{gathered}
$$

The value of discharge coefficient $C_{R H}$ for an orifice plate with flange pressure tappings was calculated according to Reader-Harris/Gallagher equation [15] for the actual Reynolds numbers as follows

$$
\begin{gathered}
C_{\mathrm{RH}}=0.5961+0.0261 \beta^{2}-0.216 \beta^{8}+ \\
+0.000521\left(\frac{10^{6} \beta}{\operatorname{Re}}\right)^{0.7}+(0.0188+0.0063 A) \beta^{3.5}\left(\frac{10^{6}}{\mathrm{Re}}\right)^{0.3}+ \\
+\left(0.043+0.08 e^{-10 L_{1}}-0.123 e^{-7 L_{1}}\right)(1-0.11 A) \frac{\beta^{4}}{1-\beta^{4}}- \\
-0.031\left(M_{2}^{\prime}-0.8 \cdot M_{2}^{\prime 1.1}\right) \beta^{1.3}+M_{3},
\end{gathered}
$$

where

$$
\begin{gathered}
A=\left(\frac{19000 \beta}{\operatorname{Re}}\right)^{0.8} ; L_{1}=L_{2}=\frac{0.0254}{D} ; M_{2}^{\prime}=\frac{2 L_{2}}{1-\beta} ; \\
M_{3}=\left\{\begin{array}{l}
0 \text { for } D \geq 0.07112 \mathrm{~m} ; \\
0.011(0.75-\beta)\left(2.8-\frac{D}{0.0254}\right) \text { for } D<0.07112 \mathrm{~m} .
\end{array}\right.
\end{gathered}
$$


The experimental values of air expansibility factor $\varepsilon_{S}[14]$ and the new corrected values of air expansibility factor $\varepsilon_{N e}$ calculated according to equation (10) are presented in Table 1.

Table 1. Experimental values and corrected values of air expansibility factor.

\begin{tabular}{|c|c|c|c|c|c|c|c|c|c|}
\hline \multirow{2}{*}{$\#$} & \multicolumn{3}{|c|}{$\beta=0.2420 ; C_{\infty}=0.59739$} & \multicolumn{3}{|c|}{$\beta=0.3630 ; C_{\infty}=0.59947$} & \multicolumn{3}{|c|}{$\beta=0.4840 ; C_{\infty}=0.60256$} \\
\hline & $\varepsilon_{S}$ & $C_{R H}$ & $\varepsilon_{N e}$ & $\varepsilon_{S}$ & $C_{R H}$ & $\varepsilon_{N e}$ & $\varepsilon_{S}$ & $C_{R H}$ & $\varepsilon_{N e}$ \\
\hline 1 & 0.99901 & 0.60243 & 0.99065 & 0.99518 & 0.60347 & 0.98857 & 0.99790 & 0.60609 & 0.99209 \\
\hline 2 & 0.99838 & 0.60242 & 0.99004 & 0.99711 & 0.60347 & 0.99051 & 0.99784 & 0.60608 & 0.99204 \\
\hline 3 & 0.99757 & 0.60242 & 0.98924 & 0.99887 & 0.60346 & 0.99226 & 0.99772 & 0.60608 & 0.99192 \\
\hline 4 & 0.99819 & 0.60242 & 0.98985 & 1.00094 & 0.60346 & 0.99432 & 0.99733 & 0.60609 & 0.99152 \\
\hline 5 & 0.99624 & 0.60241 & 0.98793 & 0.99785 & 0.60345 & 0.99127 & 0.99603 & 0.60608 & 0.99024 \\
\hline 6 & 0.99299 & 0.60241 & 0.98471 & 0.99561 & 0.60345 & 0.98904 & 0.99299 & 0.60608 & 0.98722 \\
\hline 7 & 0.98825 & 0.60241 & 0.98001 & 0.99065 & 0.60345 & 0.98412 & 0.98655 & 0.60608 & 0.98081 \\
\hline 8 & 0.97587 & 0.60241 & 0.96774 & 0.98438 & 0.60344 & 0.97789 & 0.98100 & 0.60608 & 0.97529 \\
\hline 9 & 0.98860 & 0.60241 & 0.98036 & 0.99130 & 0.60344 & 0.98477 & 0.98655 & 0.60608 & 0.98081 \\
\hline 10 & 0.96597 & 0.60241 & 0.95792 & 0.97277 & 0.60344 & 0.96636 & 0.96903 & 0.60609 & 0.96339 \\
\hline 11 & 0.94320 & 0.60240 & 0.93535 & 0.96224 & 0.60344 & 0.95590 & 0.95927 & 0.60609 & 0.95369 \\
\hline 12 & 0.93030 & 0.60240 & 0.92255 & 0.94871 & 0.60344 & 0.94247 & 0.94593 & 0.60608 & 0.94043 \\
\hline 13 & 0.94270 & 0.60240 & 0.93485 & 0.90880 & 0.60344 & 0.90282 & 0.92543 & 0.60608 & 0.92005 \\
\hline 14 & - & - & - & 0.94960 & 0.60343 & 0.94336 & 0.94530 & 0.60608 & 0.93981 \\
\hline \# & \multicolumn{3}{|c|}{$\beta=0.5445 ; C_{\infty}=0.60431$} & \multicolumn{3}{|c|}{$\beta=0.6655 ; C_{\infty}=0.60680$} & \multicolumn{3}{|c|}{$\beta=0.7260 ; C_{\infty}=0.60639$} \\
\hline 1 & 0.99911 & 0.60791 & 0.99320 & 0.99916 & 0.61212 & 0.99046 & 0.99767 & 0.61078 & 0.99050 \\
\hline 2 & 0.99800 & 0.60790 & 0.99210 & 0.99859 & 0.61211 & 0.98992 & 1.00264 & 0.61077 & 0.99545 \\
\hline 3 & 0.99672 & 0.60789 & 0.99084 & 1.00057 & 0.61210 & 0.99190 & 0.99970 & 0.61076 & 0.99254 \\
\hline 4 & 0.99840 & 0.60790 & 0.99250 & 0.99797 & 0.61211 & 0.98931 & 1.00231 & 0.61077 & 0.99511 \\
\hline 5 & 0.99484 & 0.60789 & 0.98898 & 0.99774 & 0.61209 & 0.98910 & 0.99776 & 0.61076 & 0.99061 \\
\hline 6 & 0.99226 & 0.60788 & 0.98642 & 0.99494 & 0.61209 & 0.98634 & 0.99536 & 0.61076 & 0.98823 \\
\hline 7 & 0.98612 & 0.60788 & 0.98032 & 0.99287 & 0.61209 & 0.98429 & 0.98578 & 0.61076 & 0.97872 \\
\hline 8 & 0.98066 & 0.60788 & 0.97490 & 0.98846 & 0.61208 & 0.97992 & 0.98001 & 0.61076 & 0.97300 \\
\hline 9 & 0.98624 & 0.60788 & 0.98045 & 0.98079 & 0.61208 & 0.97233 & 0.97015 & 0.61075 & 0.96321 \\
\hline 10 & 0.96970 & 0.60788 & 0.96400 & 0.98872 & 0.61208 & 0.98019 & 0.97985 & 0.61075 & 0.97284 \\
\hline 11 & 0.95974 & 0.60788 & 0.95410 & 0.97350 & 0.61207 & 0.96511 & 0.96330 & 0.61075 & 0.95642 \\
\hline 12 & 0.94191 & 0.60788 & 0.93637 & 0.96539 & 0.61207 & 0.95708 & 0.94452 & 0.61075 & 0.93777 \\
\hline 13 & 0.91182 & 0.60788 & 0.90646 & 0.94795 & 0.61206 & 0.93979 & 0.90999 & 0.61074 & 0.90350 \\
\hline 14 & 0.94230 & 0.60788 & 0.93677 & 0.92258 & 0.61206 & 0.91465 & 0.94428 & 0.61074 & 0.93755 \\
\hline 15 & - & - & - & 0.94822 & 0.61206 & 0.94007 & - & - & - \\
\hline
\end{tabular}

\section{Development of a new equation}

The most important thing when developing a new equation for gas expansibility factor is to define the structure of the equation. On the basis of the research carried out by us, we defined that the most accurate equation to fit the corrected values of air expansibility factor is

$$
\varepsilon_{\mathrm{N}}=1-a_{\mathrm{N}}-b_{\mathrm{N}}\left[1-\left(1-\frac{\Delta p}{p}\right)^{\frac{1}{\kappa}}\right] .
$$

Based on the experimental values of gas expansibility factor the values of $a_{S}$ and $b_{S}$ coefficients (they correspond to $a$ and $b$ coefficients in equation (5)) were derived by Seidl and the values of these coefficients are presented in Table 2. Using the least-squares method we have obtained the values of $a_{N}$ and $b_{N}$ coefficients to fit the corrected values of gas expansibility factor (see Table 1) and the values of these coefficients are also presented in Table 2. 
Table 2. Values of $a_{S}$ and $b_{S}$ coefficients according to the experimental data of Seidl [14] and values of $a_{N}$ and $b_{N}$ coefficients according to the corrected experimental data.

\begin{tabular}{|c|c|c|c|c|c|}
\hline \multirow{2}{*}{$\#$} & \multirow{2}{*}{$\beta$} & \multicolumn{2}{|c|}{ Experimental data $\varepsilon_{S}$} & \multicolumn{2}{c|}{ Corrected experimental data $\varepsilon_{N}$} \\
\cline { 3 - 6 } & & $a_{S}$ & $b_{S}$ & $a_{N}$ & $b_{N}$ \\
\hline \hline 1 & 0.2420 & $-1.5610 \cdot 10^{-8}$ & 0.3791 & 0.0085552 & 0.362105 \\
\hline 2 & 0.3630 & $-2.1536 \cdot 10^{-3}$ & 0.3577 & 0.0048254 & 0.338649 \\
\hline 3 & 0.4840 & $1.3816 \cdot 10^{-6}$ & 0.3834 & 0.0060568 & 0.367367 \\
\hline 4 & 0.5445 & $5.9339 \cdot 10^{-6}$ & 0.4025 & 0.0062141 & 0.383636 \\
\hline 5 & 0.6655 & $-1.1408 \cdot 10^{-4}$ & 0.4407 & 0.0087519 & 0.422299 \\
\hline 6 & 0.7260 & $2.5120 \cdot 10^{-6}$ & 0.5309 & 0.0074610 & 0.509042 \\
\hline
\end{tabular}

As we can see from Table 2, application of discharge coefficient $C_{\infty}$ calculated according to Stolz equation when defining the gas expansibility factor according to the experimental data [14] leads to the value of $a_{S}$ coefficient approaching zero. That is why $a_{S}$ coefficient can be neglected at development of equation for gas expansibility factor.

If we apply discharge coefficient $C_{R H}$ calculated according to Reader-Harris/Gallagher equation when defining the gas expansibility factor according to the corrected experimental data, the value of $a_{N}$ coefficient in equation (15) does not approach zero (see Table 2). That is why $a_{N}$ coefficient cannot be neglected at development of equation for gas expansibility factor.

Let's obtain the formulae for calculation of $a_{N}$ and $b_{N}$ coefficients defined for the corrected experimental values of gas expansibility factor.

Since $a_{N}$ coefficient is constant and it does not depend on the diameter ratio of orifice plate, it can be defined as mean value of the values given in Table 2 for the corrected experimental data of expansibility factor $\varepsilon_{N e}$ of air and its value $a_{N}=0.006977$.

Coefficient $b_{N}$ with its values given in Table 2 is a function of diameter ratio $\beta$ of orifice plate.

Using the least-squares method and the new value of $a_{N}=0.006977$ the values of $b_{N}$ coefficient shall be corrected. The corrected values of $b_{N}$ coefficient are given in Table 3 .

Based on the research we defined that the most accurate equation for $b_{N}$ coefficient is the following equation [11]

$$
b_{\mathrm{N}}=a_{b}+b_{b} \beta^{4}+c_{b} \beta^{8} .
$$

Table 3. Corrected values of $b_{N}$ coefficient.

\begin{tabular}{|c|c|c|}
\hline$\#$ & $\beta$ & $b_{N}$ \\
\hline \hline 1 & 0.2420 & 0.374214 \\
\hline 2 & 0.3630 & 0.324496 \\
\hline 3 & 0.4840 & 0.360038 \\
\hline 4 & 0.5445 & 0.378002 \\
\hline 5 & 0.6655 & 0.438676 \\
\hline 6 & 0.7260 & 0.513676 \\
\hline
\end{tabular}

Using the least-squares method the values of $a_{b}, b_{b}, c_{b}$ coefficients shall be as follows: $a_{b}=0.3507 ; b_{b}=0.0849$; $c_{b}=1.8195$.

After substituting the values of $a_{b}, b_{b}, c_{b}$ coefficients in equation (16) we obtain the equation for $b_{N}$ coefficient

$$
b_{\mathrm{N}}=0.3507+0.0849 \cdot \beta^{4}+1.8195 \cdot \beta^{8} .
$$

The absolute standard deviation $\sigma_{b}$ of values of $b_{N}$ coefficient calculated according to equation (17) from the values of $b_{N}$ coefficient given in Table 2 (reassigned as $b_{N T}$ ) for the corrected experimental data shall be calculated as follows 


$$
\sigma_{b}=\sqrt{\frac{\sum_{i=1}^{n}\left(b_{\mathrm{N} i}-b_{\mathrm{NT} i}\right)^{2}}{n-1}}=0.0123 .
$$

where $n$ is the number of values of $b_{N}$ coefficient $(n=6)$.

By substituting the equation (17) and the new value of $a_{N}$ coefficient in equation (15) we obtain a new equation for calculation of gas expansibility factor for orifice plate with flange pressure tappings

$$
\varepsilon_{\mathrm{N}}=0.993023-\left(0.3507+0.0849 \beta^{4}+1.8195 \beta^{8}\right)\left[1-\left(1-\frac{\Delta p}{p}\right)^{\frac{1}{\kappa}}\right] .
$$

The relative deviation $\delta \varepsilon_{N}$ of the corrected experimental values and the values of expansibility factor calculated according to equation (19) are given in Table 4. As we can see from Table 4, maximum relative deviation $\delta \varepsilon_{N}$ is $0.61 \%$ which is twice as little as maximum relative deviation $\delta \varepsilon_{R H}$ of values of expansibility factor calculated according to the known equation (9) which is equal $1.21 \%$. By the way the average of distribution of the relative deviation in the presented set of data is equal to $-0.004 \%$ for the new equation instead of $0.71 \%$ for the known equation.

When $\beta, \Delta p / p$ and $\kappa$ are assumed to be known without error, the expanded uncertainty of expansibility factor $\varepsilon_{N}$ calculated according to equation (19) relative to the corrected experimental values of expansibility factor $\varepsilon_{N e}$ shall be defined as follows

$$
\begin{gathered}
\varepsilon_{\mathrm{N}}-\varepsilon_{\mathrm{Ne}}= \\
=-\left(0.3507+0.0849 \beta^{4}+1.8195 \beta^{8}-b_{\mathrm{NT}}\right)\left[1-\left(1-\frac{\Delta p}{p}\right)^{\frac{1}{\kappa}}\right]=. \\
=-2 \sigma_{b}\left[1-\left(1-\frac{\Delta p}{p}\right)^{\frac{1}{\kappa}}\right]=-0.0246\left[1-\left(1-\frac{\Delta p}{p}\right)^{\frac{1}{\kappa}}\right] .
\end{gathered}
$$

Table 4. Relative deviations $\delta \varepsilon_{R H}$ and $\delta \varepsilon_{N}$ between the corrected experimental values and the values of expansibility factor calculated according to equations (9) and (19) correspondingly.

\begin{tabular}{|c|c|c|c|c|c|c|c|c|c|c|c|}
\hline$\Delta p / p$ & $\varepsilon_{N e}$ & $\varepsilon_{R H}$ & $\begin{array}{l}\delta \varepsilon_{R H} \\
(\%)\end{array}$ & $\varepsilon_{N}$ & $\begin{array}{c}\delta \varepsilon_{N} \\
(\%)\end{array}$ & $\Delta p / p$ & $\varepsilon_{N e}$ & $\varepsilon_{R H}$ & $\begin{array}{c}\delta \varepsilon_{R H} \\
(\%)\end{array}$ & $\varepsilon_{N}$ & $\begin{array}{c}\delta \varepsilon_{N} \\
(\%)\end{array}$ \\
\hline \multicolumn{9}{|c|}{$\beta=0.2420$} \\
\hline \hline 0.00336 & 0.99065 & 0.99917 & 0.86 & 0.99220 & 0.16 & 0.00298 & 0.98857 & 0.99926 & $\mathbf{1 . 0 8}$ & 0.99229 & 0.38 \\
\hline 0.00471 & 0.99004 & 0.99884 & 0.89 & 0.99186 & 0.18 & 0.00459 & 0.99051 & 0.99885 & 0.84 & 0.99188 & 0.14 \\
\hline 0.00730 & 0.98924 & 0.99819 & 0.90 & 0.99122 & 0.20 & 0.00791 & 0.99226 & 0.99801 & 0.58 & 0.99105 & -0.12 \\
\hline 0.00473 & 0.98985 & 0.99883 & 0.91 & 0.99186 & 0.20 & 0.00460 & 0.99432 & 0.99885 & 0.46 & 0.99188 & -0.25 \\
\hline 0.01265 & 0.98793 & 0.99685 & 0.90 & 0.98988 & 0.20 & 0.01665 & 0.99127 & 0.99579 & 0.46 & 0.98885 & -0.24 \\
\hline 0.02662 & 0.98471 & 0.99333 & 0.88 & 0.98637 & 0.17 & 0.02800 & 0.98904 & 0.99290 & 0.39 & 0.98598 & -0.31 \\
\hline 0.04484 & 0.98001 & 0.98872 & 0.89 & 0.98177 & 0.18 & 0.05567 & 0.98412 & 0.98580 & 0.17 & 0.97894 & -0.53 \\
\hline 0.09087 & 0.96774 & 0.97694 & 0.95 & 0.97002 & 0.24 & 0.08013 & 0.97789 & 0.97947 & 0.16 & 0.97267 & -0.53 \\
\hline 0.04484 & 0.98036 & 0.98872 & 0.85 & 0.98177 & 0.14 & 0.05574 & 0.98477 & 0.98578 & 0.10 & 0.97892 & -0.59 \\
\hline 0.13072 & 0.95792 & 0.96660 & 0.91 & 0.95971 & 0.19 & 0.12559 & 0.96636 & 0.96757 & 0.13 & 0.96087 & -0.57 \\
\hline 0.21125 & 0.93535 & 0.94528 & 1.06 & 0.93844 & 0.33 & 0.16510 & 0.95590 & 0.95708 & 0.12 & 0.95047 & -0.57 \\
\hline 0.25412 & 0.92255 & 0.93367 & $\mathbf{1 . 2 1}$ & 0.92685 & $\mathbf{0 . 4 7}$ & 0.21325 & 0.94247 & 0.94411 & 0.17 & 0.93760 & -0.52 \\
\hline 0.21195 & 0.93485 & 0.94509 & 1.10 & 0.93825 & 0.36 & 0.34600 & 0.90282 & 0.90708 & 0.47 & 0.90088 & -0.21 \\
\hline- & - & - & - & - & - & 0.21323 & 0.94336 & 0.94411 & 0.08 & 0.93761 & $\mathbf{- 0 . 6 1}$ \\
\hline \multicolumn{7}{|c|}{$\beta=0.4840$} \\
\hline
\end{tabular}




\begin{tabular}{|c|c|c|c|c|c|c|c|c|c|c|c|}
\hline 0.00290 & 0.99209 & 0.99925 & 0.72 & 0.99229 & 0.02 & 0.00269 & 0.99320 & 0.99928 & 0.61 & 0.99232 & -0.09 \\
\hline 0.00445 & .99204 & 99885 & 0.69 & 0.99189 & -0.02 & 0.00416 & 0.99210 & 0.99889 & 0.68 & 0.99193 & -0.02 \\
\hline 0.00762 & 0.99192 & 0.99802 & 0.61 & 0.99108 & -0.08 & 0.00717 & 0.99084 & 0.99807 & 0.73 & 0.99113 & 0.03 \\
\hline 0.00442 & 0.99152 & 0.99885 & 0.74 & 0.99190 & 0.04 & 0.00416 & 0.99250 & 0.99888 & 0.64 & 0.99193 & -0.06 \\
\hline 0.01593 & 0.99024 & 0.99584 & 0.57 & 0.98894 & -0.13 & 0.01511 & 0.98898 & 0.99591 & 0.70 & 0.98903 & 0.01 \\
\hline 0.02646 & 0.98722 & 0.99306 & 0.59 & 0.98622 & -0.10 & 0.02516 & 0.98642 & 0.99317 & 0.68 & 0.98635 & -0.01 \\
\hline 0.05252 & 0.98081 & 0.98615 & 0.54 & 0.97944 & -0.14 & 0.05002 & 0.98032 & 0.98636 & 0.62 & 0.97968 & -0.07 \\
\hline 0.07516 & 0.97529 & 0.98010 & 0.49 & 0.97350 & -0.18 & 0.07174 & 0.97490 & 0.98035 & 0.56 & 0.97381 & -0.11 \\
\hline 0.05224 & 0.98081 & 0.98623 & 0.55 & 0.97951 & -0.13 & 0.05006 & 0.98045 & 0.98634 & 0.60 & 0.97967 & -0.08 \\
\hline 0.11703 & 0.96339 & 0.96879 & 0.56 & 0.96241 & -0.10 & 0.11213 & 0.96400 & 0.96908 & 0.53 & 0.96279 & -0.13 \\
\hline 0.15339 & 0.95369 & 0.95885 & 0.54 & 0.95266 & -0.11 & 0.14651 & 0.95410 & 0.95937 & 0.55 & 0.95329 & -0.08 \\
\hline 0.19803 & 0.94043 & 0.94647 & 0.64 & 0.94051 & 0.01 & 0.20188 & 0.93637 & 0.94348 & 0.76 & 0.93776 & 0.15 \\
\hline 0.26719 & 0.92005 & 0.92688 & 0.74 & 0.92130 & 0.14 & 0.30080 & 0.90646 & 0.91428 & 0.86 & 0.90921 & 0.30 \\
\hline 0.19847 & 0.93981 & 0.94634 & 0.69 & 0.94039 & 0.06 & & 0.93677 & 0.94353 & 0.72 & 0.93781 & 0.11 \\
\hline \multicolumn{6}{|c|}{$\beta=0.6655$} & \multicolumn{6}{|c|}{$\beta=0.7260$} \\
\hline 0.00136 & 0.99046 & 0.99958 & 0.92 & 0.99260 & 0.22 & 0.00176 & 0.99050 & 0.99939 & 0.90 & 0.99239 & 0.19 \\
\hline 0.00235 & 0.98992 & 0.99927 & 0.94 & 0.99230 & 0.24 & 0.00267 & 0.99545 & 0.99907 & 0.36 & 0.99206 & -0.34 \\
\hline 0.00491 & 0.99190 & 0.99848 & 0.66 & 0.99150 & -0.04 & 0.00460 & 0.99254 & 0.99839 & 0.59 & 0.99135 & -0.12 \\
\hline 0.00236 & 0.98931 & 0.99927 & 1.01 & 0.99229 & 0.30 & 0.00266 & 0.99511 & 0.99908 & 0.40 & 0.99206 & -0.31 \\
\hline 0.00818 & 0.98910 & 0.99746 & 0.85 & 0.99048 & 0.14 & 0.00964 & 0.99061 & 0.99662 & 0.61 & 0.98950 & -0.11 \\
\hline 0.01616 & 0.98634 & 0.99496 & 0.87 & 0.98798 & 0.17 & 0.01600 & 0.98823 & 0.99438 & 0.62 & 0.98716 & -0.11 \\
\hline 0.02301 & 0.98429 & 0.99282 & 0.87 & 0.98584 & 0.16 & 0.03201 & 0.97872 & 0.98870 & 1.02 & 0.98125 & 0.26 \\
\hline 0.03548 & 0.97992 & 0.98890 & 0.92 & 0.98191 & 0.20 & 0.04593 & 0.97300 & 0.98375 & 1.10 & 0.97608 & 0.32 \\
\hline 0.06175 & 0.97233 & 0.98059 & 0.85 & 0.97360 & 0.13 & 0.07155 & 0.96321 & 0.97457 & 1.18 & 0.96652 & 0.34 \\
\hline 0.03555 & 0.98019 & 0.98888 & 0.89 & 0.98189 & 0.17 & 0.04593 & 0.97284 & 0.98374 & 1.12 & 0.97608 & 0.33 \\
\hline 0.08779 & 0.96511 & 0.97229 & 0.74 & 0.96529 & 0.02 & 0.09319 & 0.95642 & 0.96675 & 1.08 & 0.95837 & 0.20 \\
\hline 0.11261 & 0.95708 & 0.96431 & 0.76 & 0.95731 & 0.02 & 0.14652 & 0.93777 & 0.94726 & 1.01 & 0.93806 & 0.03 \\
\hline 0.16720 & 0.93979 & 0.94654 & 0.72 & 0.93952 & -0.03 & 0.24465 & 0.90350 & 0.91045 & 0.77 & 0.89970 & $\begin{array}{l}-0.42 \\
\end{array}$ \\
\hline 0.24252 & 0.91465 & 0.92145 & 0.74 & 0.91441 & -0.03 & 0.14652 & 0.93755 & 0.94726 & 1.04 & 0.93806 & 0.05 \\
\hline 0.16715 & 0.94007 & 0.94655 & 0.69 & 0.93953 & -0.06 & - & - & - & - & - & - \\
\hline
\end{tabular}

In percentage terms the relative expanded uncertainty of calculation of expansibility factor is defined as follows

$$
\frac{2.46\left[1-\left(1-\frac{\Delta p}{p}\right)^{\frac{1}{\kappa}}\right]}{0.993023-\left(0.3507+0.0849 \beta^{4}+1.8195 \beta^{8}\right)\left[1-\left(1-\frac{\Delta p}{p}\right)^{\frac{1}{\kappa}}\right]} .
$$

After decomposing the term $\left[1-(1-\Delta p / p)^{1 / \kappa}\right]$ in the numerator of equation (21) into Maclaurin series for the value of $\Delta p / p$ and after taking its first term $\Delta p /(\kappa \cdot p)$, for $\beta=0.75, \Delta p / p=0.25$ and $\kappa=1$ in the denominator of equation (21) when the value of the uncertainty is maximal, we obtain a new formula for the relative expanded uncertainty of expansibility factor

$$
2.88 \cdot \frac{\Delta p}{\kappa \cdot p}
$$

As it was expected, formula (22) in comparison to the known analogous formula in [15] gives smaller values of the relative expanded uncertainty of expansibility factor for equal input values. 


\section{Conclusions}

It is shown that during experimental research works on gas expansibility factor a number of coefficients of flowrate equation, and discharge coefficient in particular, are used to define the values of expansibility factor and inaccuracy of these coefficients makes influence on the uncertainty of expansibility factor.

It is defined that the formulae in force at present for gas expansibility factor include a systematic component error caused by the following factors:

- the known formulae for expansibility factor are derived with application of Stolz equation for calculation of orifice plate discharge coefficient and a larger value of uncertainty is assigned to this equation in comparison to Reader-Harris/Gallagher equation;

- the experimental values of expansibility factor were defined according to the values of orifice plate discharge coefficient calculated not for the actual Reynolds numbers but for Reynolds numbers equal to infinity.

By taking into account the actual values of orifice plate discharge coefficient, the experimental data for gas expansibility factor are defined more accurately for orifice plates with flange pressure tappings.

New equation for gas expansibility factor for orifice plates with flange pressure tappings is developed and it provides higher accuracy according to the existing experimental data. The average distribution of the relative deviation and the maximal relative deviation for the existing set of experimental data are $-0.004 \%$ and $0.61 \%$ correspondingly for the new developed equation instead of $0.71 \%$ and $1.21 \%$ correspondingly for the known formula.

New equation for relative expanded uncertainty of expansibility factor is developed with taking into account the influencing parameters of fluid and flow. The new equation provides decrease of relative expanded uncertainty of expansibility factor.

\section{References}

[1] Buckingham E. Notes on the orifice meter: the expansion factor for gases / E. Buckingham // Bureau of Standards Journal of Research, Research Paper. - 1932. - No. 459, Vol.9.

[2] ISO 5167-1:1991 (E). Measurement of fluid flow by means of pressure differential devices. - Part 1: Orifice plates, nozzles and Venturi tubes inserted in circular cross-section conduits running full.

[3] Rules for measurement of flowrate of gases and liquids by means of standard pressure differential devices: RD 50-213-80. - Official document. - Moscow: Publishing house of standards, 1982. (in Russian)

[4] Measurement of flowrate and volume of liquids and gases by means of pressure differential method. Orifice plates, ISA 1932 nozzles and Venturi tubes inserted in circular cross-section conduits running full. Technical conditions: GOST 8.563.1-97 GSI. - [Valid since 01.01.1997]. - Moscow: Publishing house of standards, 1998. (in Russian)

[5] Reader-Harris M. J., Sattary J. A. and Spearman E. P. The orifice plate discharge coefficient equation. Progress Report № PR14: EUEC/17 (EEC005). East Kilbride, Glasgow: National Engineering Laboratory Executive Agency. - May 1996.

[6] Reader-Harris M.J. and Sattary J.A. The orifice plate discharge coefficient equation - the equation for ISO 5167-1. In proc. of 14th North Sea Flow Measurement Workshop, Peebles, Scotland, East Kilbride, Glasgow, National Engineering Laboratory, October 1996. - P. 24.

[7] Experimental data for the determination of basic $50 \mathrm{~mm}$ orifice plate discharge coefficients - European programme for commission of the European Communities. Rep. N PR12: EUEC/17 (EEC005), May 1992.

[8] Experimental data for the determination of basic $600 \mathrm{~mm}$ orifice plate discharge coefficients - European programme compiled by E.P. Spearman and J.A. Sattary (Flow Centre) NEL, East Kilbride, Scotland. Rep. N PR12: EUEC/17 (EEC005), May 1992.

[9] Gasunie Research. Orifice measurements according to ISO 5167 at Bernoulli Laboratory / Westerbork. Rep. RG 02.0326, May 2002.

[10] Thibessard G. Über die Expansionszahl bei der Durchflußmessung mit Normblenden / G. Thibessard. - Brennstoff-Wärme-Kraft, 1960. Vol. 12, Nr. 3. - P. $97-101$.

[11] Reader-Harris M.J. The equation for the expansibility factor for orifice plates / M.J. Reader-Harris // FLOMEKO 98. - Sweden, June 1998. P. 209-214.

[12] Reid J. Tests to determine orifice plate expansibility factors. Progress Report No, PR6: EUEC/03 for EEC.Community Bureau of Reference (BCR) / J. Reid / East Kilbride, Scotland: National Engineering Laboratory. - 1981.

[13] NATIONAL ENGINEERING LABORATORY. Commissioning tests with $0.2 \beta$ ratio plate in EEC expansibility rig in air with Re ef $_{d} 35000$ and reexamination of existing EEC data on expansibility. Report No. EUEC/21 for EEC Community Bureau of Reference (BCR). East Kilbridge, Scotland: National Engineering Laboratory, November. - 1988.

[14] SEIDL W. The orifice expansion correction for a $50 \mathrm{~mm}$ line size at various diameter ratios. / W. SEIDL // In Proc. 3rd Int. Symp. On Fluid Flow Measurement, San Antonio, Texas. - 1995.

[15] Measurement of fluid flow by means of pressure differential devices inserted in circular cross-section conduits running full: ISO 51672:2003. - Part 2: Orifice plates. 


\title{
Розрахунок коефіціснта розширення газу при його протіканні через діафрагму з фланцевим відбором тиску
}

\author{
Євген Пістун, Леонід Лесовой \\ Національний університет «Львівська політехніка», вул. С. Бандери, 12, м. Львів, 79013, Украӥна
}

\begin{abstract}
Анотація
У статті наведені уточнені значення коефіцієнта розширення газу на основі значень отриманих Давидом Зейдлем у Колорадському інженерно-експериментальному центрі (CEESI) із застосуванням рівняння масової витрати газу для діафрагми 3 фланцевим способом відбору тиску і значень відносного діаметра отвору діафрагми від 0,242 до 0,728 для значення внутрішнього діаметру трубопроводу 52,48 мм (2,066 дюйма). При отриманні значень коефіцієнта розширення Зейдль застосував рівняння коефіцієнта витікання Штольца для значення числа Рейнольдса рівного нескінченності. Авторами були уточнені значення коефіцієнта розширення газу, застосовуючи нове рівняння коефіцієнта витікання Рідера-Харіса/Галахера для реальних значень числа Рейнольдса. На базі уточнених значень коефіцієнта розширення газу авторами було розроблене нове рівняння для його розрахунку, що зменшило максимальне відхилення значення коефіцієнта розширення газу відносно рівняння, яке застосовується в ISO 5167-2:2003. Авторами також розроблено нове рівняння для розрахунку відносної розширеної невизначеності коефіцієнта розширення повітря, яке також наведене у статті.
\end{abstract}

Ключові слова: коефіцієнт розширення; вимірювання витрати; діафрагма; фланцевий спосіб відбору тиску; невизначеність коефіцієнта розширення. 